\title{
Ectopic scrotum: A unique case report
}

\section{H. Krishna Moorthy, MD; Biju S. Pillai, MD; Renjeeth Singh Rathore, MD; Nisarg Mehta, MD}

Department of Urology, Lourdes Hospital, Kochi, India

Cite as: Can Urol Assoc J 2015;9(9-10):E665-6. http://dx.doi.org/10.5489/cuaj.2419 Published online September 9, 2015.

\section{Abstract}

Ectopic scrotum is a rare congenital anomaly. Most common location is supra-inguinal. We present a case of left ectopic scrotum in a three year old boy with no associated congenital anomalies, who underwent successful scrotoplasty and orchiopexy.

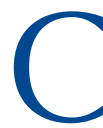

ongenital scrotal anomalies are classified as penoscrotal transposition, bifid scrotum, ectopic scrotum, and accessory scrotum. ${ }^{1}$ Ectopic scrotum is the anomalous position of one hemi-scrotum along the inguinal canal. Ectopic scrotum is rare and can occur anywhere from the inguinal canal to the perineum and mid-thigh, but occurs mainly in the inguinal, supra-inguinal, infra-inguinal or perineal areas. ${ }^{2}$

Associated anomalies include inguinal hernia, cryptorchidism, and exstrophy of the bladder. About $70 \%$ of suprainguinal ectopic scrotums are associated with ipsilateral

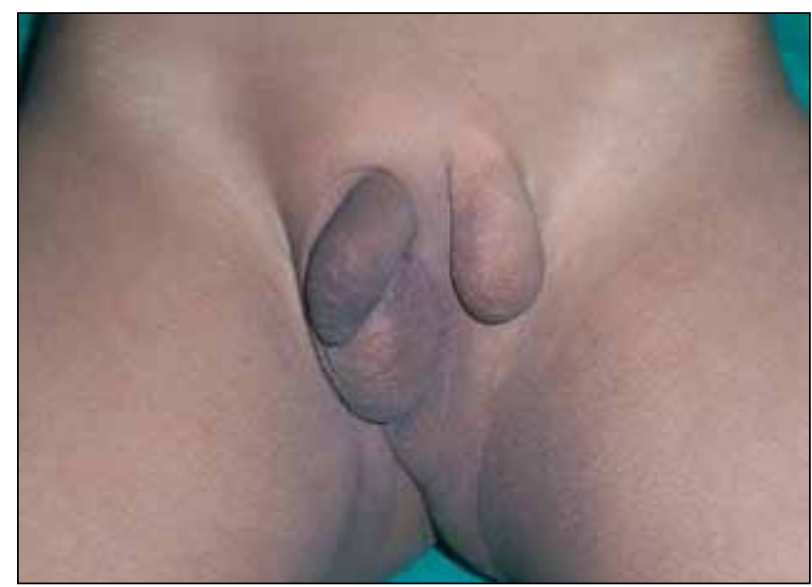

Fig. 1. A clinical picture of the ectopic scrotum. upper tract anomalies, like renal agenesis, renal dysplasia and ectopic ureter. ${ }^{3}$

Embryonically it is believed that ectopic scrotum develops due to a defect in the gubernacular development. ${ }^{4}$ Lockwood described 4 locations of distal gubernacular attachment: pubic area, superficial inguinal area, saphenous area, and perineal area. ${ }^{5}$

Six to twelve months of age is considered appropriate for scrotoplasty and orchiopexy. ${ }^{6-8}$

\section{Case report}

A 3-year-old boy presented with a swelling in left inguinal region since birth. There was no family history of congenital anomalies. On physical examination, the right hemi-scrotum was normally located and contained normal sized right testis. Left hemi-scrotum was located in the left inguinal region and contained normal sized left testis (Fig. 1). Ultrasound evaluation of abdomen did not reveal any other associated anomalies.

The child underwent exploration of the left hemiscrotum (Fig. 2) scrotoplasty with orchiopexy (Fig. 3). He was well at the 1-year follow-up visit.

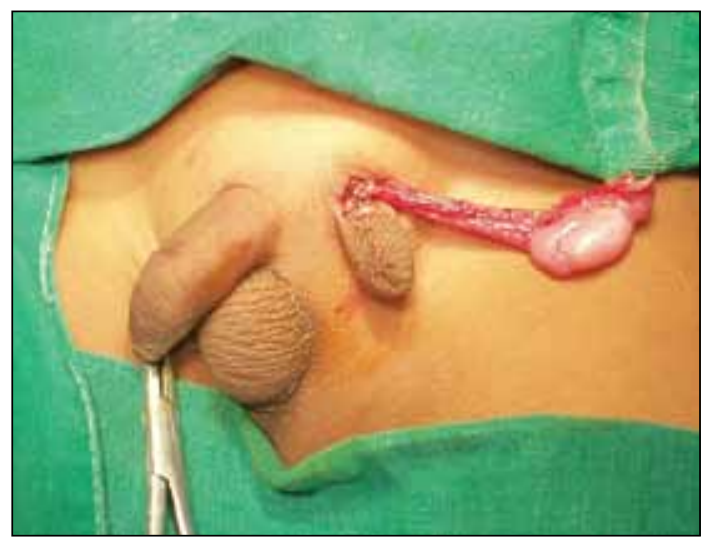

Fig. 2. Testis dissected from the ectopic scrotum. 
Moorthy et al.

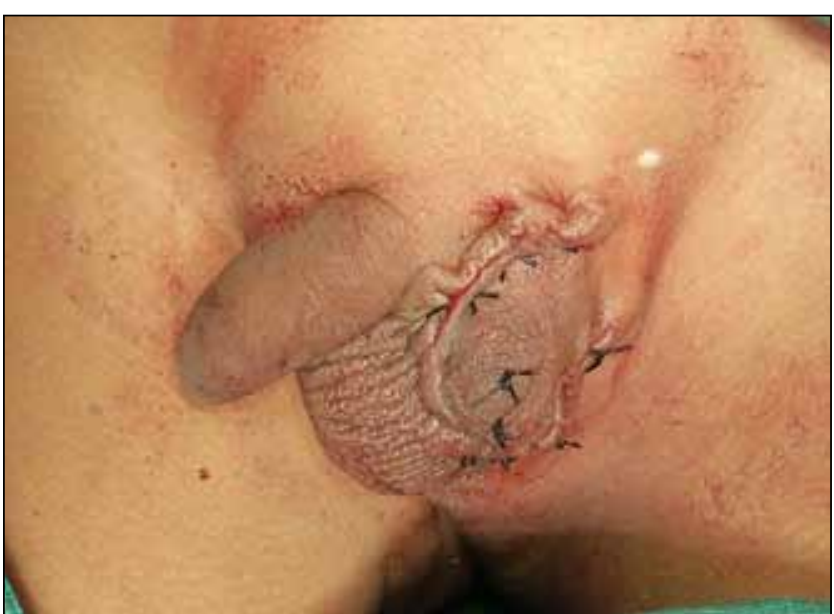

Fig. 3. Reconstructed scrotum.

Competing interests: The authors declare no competing financial or personal interests.

\section{References}

1. MacDonald MF, Spencer JB, Kass EJ. Abnormalities of the penis and scrotum. In. Kelalis PP, King LR, Belman AB (eds). Clinical Pediatric Urology. Informa Healthcare, UK; 2007:1246.

2. Milroy E. Ectopic scrootum. A review of the literature and report of a further case. Br I Urol 1969;41:235-7. http://dx.doi.org/10.1111/i.1464-410X.1969.tb09929.x

3. Elder JS, Jeffs RD. Suprainguinal ectopic scrotum and associated anomalies. J Urol 1982;127:336-8.

4. Spears T, Franco I, Reda EF, et al. Accessory and ectopic scrotum with VATER association. Urology 1992;40:343-5. http://dx.doi.org/10.1016/0090-4295(92)90385-A

5. Lockwood CB. Development and transition of testis, normal and abnormal. J Anat Physiol 1988;22:254.

6. Kumar V, Marulaiah M, Chattopadhyay A, et al. Unilateral inguinal ectopic scrotum with covered exstrophy. Pediatr Surg Int 2002; 18:51 1-3. http://dx.doi.org/10.1007/s00383-002-0731-5

7. Atul K, Mahendra S, Rajesh T, et al. Ectopic scrotum: A rare clinical entity. Uro Today Int J 2012:5:art 68. http://dx.doi.org/10.3834/uij.1944-5784.2012.12.13

8. Wein AJ, Kavoussi LR, Novick AC, et al. Campbell-Walsh Urology, 10th ed, Elsevier-Saunders, Philadelphia, PA; 2012:3555.

Correspondence: Dr. H. Krishna Moorthy, Consultant Urologist, Department of Urology, Lourdes Hospital, Kochi 682 012, S. India; dr.moorthy65@gmail.com

This paper has been peer-reviewed. 